\title{
Linkage analysis of HLA and candidate genes for celiac disease in a North American family-based study Susan L Neuhausen ${ }^{* 1}$, Michael Feolo ${ }^{1,2}$, James Farnham ${ }^{1}$, Linda Book3 and John J Zone4
}

Address: ${ }^{1}$ Medical Informatics, University of Utah, Salt Lake City, UT, USA, ${ }^{2}$ National Center for Biotechnology Information, National Library of Medicine, National Institutes of Health, Bethesda, MD, USA, 3Pediatric Gastroenterology and Nutrition, Department Pediatrics, University of Utah, Salt Lake City, UT, USA and 4Dermatology, University of Utah, Salt Lake City, UT, USA

E-mail: Susan L Neuhausen* - susan@genepi.med.utah.edu; Michael Feolo - feolo@ncbi.nlm.nih.gov;

James Farnham - jfarnham@genepi.med.utah.edu; Linda Book - pclbook@ihc.com; John J Zone - zone@ultraderm.med.utah.edu

*Corresponding author

Published: 30 November 2001

Received: 4 October 2001

BMC Medical Genetics 200I, 2:12

Accepted: 30 November 2001

This article is available from: http://www.biomedcentral.com/I47I-2350/2/12

(c) 200 I Neuhausen et al; licensee BioMed Central Ltd. Verbatim copying and redistribution of this article are permitted in any medium for any noncommercial purpose, provided this notice is preserved along with the article's original URL. For commercial use, contact info@biomedcentral.com

\begin{abstract}
Background: Celiac disease has a strong genetic association with HLA. However, this association only explains approximately half of the sibling risk for celiac disease. Therefore, other genes must be involved in susceptibility to celiac disease. We tested for linkage to genes or loci that could play a role in pathogenesis of celiac disease.
\end{abstract}

Methods: DNA samples, from members of 62 families with a minimum of two cases of celiac disease, were genotyped at HLA and at 13 candidate gene regions, including CD4, CTLA4, four Tcell receptor regions, and 7 insulin-dependent diabetes regions. Two-point and multipoint heterogeneity LOD (HLOD) scores were examined.

Results: The highest two-point and multipoint HLOD scores were obtained in the HLA region, with a two-point HLOD of 3.1 and a multipoint HLOD of 5.0. For the candidate genes, we found no evidence for linkage.

Conclusions: Our significant evidence of linkage to HLA replicates the known linkage and association of HLA with CD. In our families, likely candidate genes did not explain the susceptibility to celiac disease.

\section{Background}

Celiac disease (CD) is a common, familial, autoimmune gastrointestinal disease. It is caused by sensitivity to the dietary protein gluten, which is present in wheat, rye and barley. Symptoms include growth failure, abdominal pain, and diarrhea. Dermatitis herpetiformis is a cutaneous manifestation of CD. Complications of $\mathrm{CD}$ include lymphoma, osteoporosis, anemia, and seizures. The prevalence of CD in the US is 1:250 [1] and the ratio of symptomatic to asymptomatic cases is between 1:5 and 1:7 [2]. Before the advent of serological testing for diagnosing $\mathrm{CD}$, it was considered a rare disease in the US.

The clinical standard for diagnosis of CD is a small intestinal biopsy showing villus atrophy and resolution of symptoms on a gluten-free diet. However, small intestinal biopsy is expensive, invasive, and often rejected by the US patient population. The serological IgA endomy- 
sial antibody (EMA) test is a screening tool that has greatly facilitated evaluation for $\mathrm{CD}$ in people with suggestive symptoms and in high-risk populations. IgA EMA testing has proven to be greater than 95\% sensitive for adults and children with classic symptomatic CD [310] and greater than $98 \%$ specific in controls without known clinical disease $[11,12]$. It is therefore an inexpensive and specific method of screening family members for genetic studies. Moreover, a recent study has identified symptomatic EMA positive individuals who have $C D$ in whom intestinal biopsies were normal with only minor mucosal lesions. All the patients showed clinical and serological recovery on a gluten-free diet. They propose that sero-logic criteria may be more definitive in the diagnostic process than traditional biopsy criteria [13].

CD has a strong genetic association with the HLA class II DQ2 genotype composed of the DQA1 ${ }^{*} \mathrm{O} 5$ and $\mathrm{DQB1}{ }^{*} \mathrm{O} 2$ alleles [14]. However, the HLA association alone is insufficient to explain the hereditary nature of the disease, and is estimated to explain less than half the sibling risk [15-18]. There appears to be genetic heterogeneity, implying that more than one additional gene is involved in the disease. With current analysis software, it is possible to map complex traits like $\mathrm{CD}$, where several genetic loci are probably involved and the mode of inheritance is unclear.

One first step to identifying genes predisposing to $\mathrm{CD}$ is to investigate candidate genes. Likely candidates include the classes of genes involved in immune function, e.g., Tcell receptor (TCR) genes and immune-modulating genes. Other candidate genes are those from associated, independent diseases in which there is a higher rate of $\mathrm{CD}$ than in the general population, e.g., other autoimmune diseases such as insulin dependent diabetes mellitus (IDDM). These associations may be explained by common gene(s) responsible for both diseases or the diseases may share a similar autoimmune pathogenic mechanism [19]. There have been several European studies to localize genes for $\mathrm{CD}$, but no significant evidence for linkage has been reported other than at HLA [20-29].

In this first study of families with CD from North America, we investigated linkage to several candidate genes that could play a role in the pathogenesis of CD using 62 families with at least two cases of CD.

\section{Methods}

\section{Ascertainment of families with CD}

Families with at least two cases of CD or dermatitis herpetiformis were ascertained through local gastroenterologists, gluten intolerance support groups, and advertising at local and national celiac disease support
Table I: Characteristics of CD Cases in the Study Population*

\section{$\mathrm{N}(\%)$}

Number of cases

175

Number of pedigrees

Number of males

Number of females

Diagnostic group:

DI: Intestinal biopsy

D2: Skin biopsy

D3: Positive serum test

62

$55(31 \%)$

$120(69 \%)$

$115(66 \%)$

$12(7 \%)$

$48(27 \%)$

*Of the 175 affecteds, $90 \%$ carried the HLA DQ2 genotype, with the majority of the remainder being DQ8. For those affecteds diagnosed by serology with no biopsy, $94 \%$ had the DQ2 genotype (45/48) and the remaining 3 affecteds were DQ8.

meetings. There was no selection of cases based on sex or race, although all individuals were Caucasian. None of the families appear to be related. The research study was approved by the University of Utah Health Sciences Center Institutional Review Board. Participants ranged in age from 2 years to $100+$ years. Blood samples were collected from affected individuals and their first-degree relatives. For more distantly related cases, we also collected blood from individuals that are connections between the cases. For example, for two affected grandchildren (with different parents) and an affected grandparent, we would collect samples from the grandchildren, their parents, and the grandparent. The breakdown of the affected individuals is shown in Table 1.

\section{Diagnostic criteria}

Medical records were obtained to confirm previous biopsy-proven CD or dermatitis herpetiformis. IgA EMA testing was performed for participants who did not have a biopsy proven diagnosis of CD or dermatitis herpetiformis. Since IgA EMA is highly sensitive and specific for $\mathrm{CD}$, we did not require biopsy confirmation for phenotype assignment.

IgA EMA was measured by indirect immunofluorescence using primate smooth muscle (IMCO Diagnostics, Buffalo, New York) as substrate [30]. IgA EMA titers greater than or equal to $1: 5$ were considered positive. Limiting dilution was performed on the positive sera.

\section{Genotyping at short tandem repeat markers (STRs)}

DNA was extracted from lymphocytes using PureGene DNA isolation kits (Gentra Systems Inc.). HLA DQA1 and DQB1 genotypes were determined as described in Feolo et al. [31]. Genotyping of DNA samples from 175 affected individuals, their parents, and any connecting rel- 
Table 2: Two-point and Multi-point HLODs at Markers for HLA and I 3 Candidate Genes

\begin{tabular}{|c|c|c|c|c|c|c|c|}
\hline $\begin{array}{l}\text { Candidate } \\
\text { gene }\end{array}$ & Chromosome & Position (cM) & Marker & $\begin{array}{l}\text { Number } \\
\text { families * }\end{array}$ & Model & Best two-point HLOD $(\alpha / \theta)+$ & $\begin{array}{l}\text { Positive multi-point } \\
\operatorname{HLOD}(\alpha)\end{array}$ \\
\hline$C D 4$ & 12 pter-pl2 & 16.4 & CD4 & 44 & $\operatorname{Rec}$ & 0.0 & \\
\hline \multirow[t]{2}{*}{ CTLA-4 } & $2 q 33$ & 198.7 & CTLA4A/G & 36 & Dom/Rec & 0.0 & \\
\hline & & 198.7 & CTLA4-STR & 48 & Dom/Rec & 0.0 & \\
\hline \multirow[t]{2}{*}{ IDDM3 } & $15 q 26$ & 109.3 & DI5SI07 & 47 & Dom & $0.14(0.15 / 0.0)$ & 0 \\
\hline & & 115.9 & DI5S87 & 47 & Dom & 0.0 & \\
\hline IDDM4 & $|I q| 3$ & 85.5 & GATA30G0I & 47 & Dom & $0.29(1.00 / 0.40)$ & \\
\hline \multirow[t]{3}{*}{ IDDM5 } & $6 q 25$ & 146.1 & GATAI84A08 & 35 & Dom/Rec & 0.0 & $0.19(0.13) @ 154$ cM \\
\hline & & 154.1 & D6S44I & 45 & $\operatorname{Rec}$ & $0.15(1.00 / 0.3)$ & \\
\hline & & 154.6 & GATAI65G02 & 46 & Dom/Rec & 0.0 & \\
\hline IDDM6 & $|8 q 2|$ & 84.8 & DI8S64 & 41 & Dom/Rec & 0.0 & \\
\hline \multirow[t]{2}{*}{ IDDM7 } & $6 q 27$ & 173.3 & D6SI 277 & 39 & Dom/Rec & 0.0 & \\
\hline & & 187.2 & D6S1027 & 40 & Dom/Rec & 0.0 & \\
\hline \multirow[t]{2}{*}{ IDDM9 } & $3 q 22-q 25$ & 126.8 & D3S3044 & 46 & $\operatorname{Rec}$ & $0.84(0.05 / 0.0)$ & $0.03(0.03) @ 127$ cM \\
\hline & & 133.9 & D3SI558 & 54 & $\operatorname{Rec}$ & $0.02(0.05 / 0.1)$ & \\
\hline IDDMIO & $|0 p||-q| \mid$ & 70.2 & DIOS220 & 45 & Dom & $0.69(1.00 / 0.20)$ & \\
\hline $\operatorname{TCR} \alpha$ & $|4 q| 1.2$ & 6.5 & DI4S26I & 43 & Dom & $0.34(1.00 / 0.30)$ & \\
\hline and & & 13.9 & DI4S283 & 44 & Dom & $0.18(1.00 / 0.40)$ & \\
\hline TCR $\delta$ & & 22.7 & DI4S64 & 37 & Dom & $0.34(1.00 / 0.30)$ & \\
\hline \multirow[t]{3}{*}{$\operatorname{TCR} \beta$} & $7 q 35$ & 144.7 & D7S495 & 45 & $\operatorname{Rec}$ & $0.25(1.00 / 0.30)$ & 0.42(0.19)@।45 cM \\
\hline & & 155.1 & D7S794 & 48 & $\operatorname{Rec}$ & $0.66(1.00 / 0.20)$ & \\
\hline & & 162.3 & D7S636 & 37 & $\operatorname{Rec}$ & 0 & \\
\hline \multirow[t]{4}{*}{$T C R \gamma$} & $7 p 15-p \mid 4$ & 28.7 & D7S507 & 51 & $\operatorname{Rec}$ & $0.01(0.80 / 0.40)$ & 0 \\
\hline & & 34.7 & D7S493 & 39 & $\operatorname{Rec}$ & $0.24(1.00 / 0.30)$ & \\
\hline & & 39.8 & D7S529 & 56 & $\operatorname{Rec}$ & 0.0 & \\
\hline & & 41.7 & D7SI 808 & 49 & $\operatorname{Rec}$ & 0.0 & \\
\hline \multirow[t]{4}{*}{ HLA } & $6 p 21.3$ & 44.4 & D6S276 & 34 & Dom & $1.48(0.95 / 0.10)$ & $5.02(0.66) @ 55$ cM \\
\hline & & 49.5 & D6S291 & 35 & Dom & $1.60(1.00 / 0.10)$ & \\
\hline & & 60.4 & D6S426 & 28 & Dom & $3.10(1.00 / 0.10)$ & \\
\hline & & 66.4 & $\mathrm{D} 6 \mathrm{~S} 282$ & 30 & Dom & $1.52(0.45 / 0.00)$ & \\
\hline
\end{tabular}

*There were a total of 62 families, however not all families were genotyped for all markers or missing genotypes precluded analysis in the family. + $\alpha=$ proportion of families linked ; $\theta=$ recombination fraction; Best HLOD from the analyses of dominant and recessive models

atives from 62 families was performed with 25 markers at 13 candidate gene regions and 4 markers at HLA. However, all families were not genotyped with all markers, because some families were collected after genotyping had been done for some of the STRs. The candidate gene regions, markers, and chromosomal locations are listed in Table 2. For all markers, amplification of $20 \mathrm{ng}$ genomic DNA in a total reaction mix of $10 \mu \mathrm{l}$ was performed according to standard PCR procedures, with minor modifications to optimize product clarity. Genotyping was performed either using an ABI373 or radioactively using polyacrylamide gels. Genotypic data were stored in the same database as all kindred and phenotype information.

\section{Linkage analysis methods}

Analyses were performed using dominant and recessive genetic models, each with 2 liability classes of either affected or unknown/unaffected based on diagnostic crite- ria (Table 3). For each model, unaffected individuals and individuals with serology or biopsy based diagnosis were given a penetrance function based on disease prevalence. For linkage analysis, we used the FASTLINK [32] implementation of the LINKAGE program [33,34] for twopoint analysis, and the GENEHUNTER program [35] for both parametric and non-parametric (NPL) multi-point analyses. Two-point linkage in the presence of locus heterogeneity was assessed by the admixture test of Ott, using HOMOG [36]. We used a heterogeneity LOD (HLOD) of $>1.3$ to indicate nominal evidence for linkage for all linkage analyses [37].

\section{Results}

Candidate genes were selected based on function of those genes (i.e., T-cell receptors, CTLA4, and CD4) or from loci of associated diseases (i.e., IDDM). Although associated diseases were not considered in the selection of families, in several families, members had IDDM. In one 
Table 3: Models used in the analysis with penetrance classes by diagnostic class $(D=$ disease allele)

Diagnosis

dd Dd DD

\begin{tabular}{|c|c|c|c|}
\hline & \multicolumn{3}{|c|}{ Dominant model (disease allele frequency $=0.000 \mathrm{I}$ ) } \\
\hline Biopsy or EMA+ & 0.001 & 0.5 & 0.5 \\
\hline \multirow[t]{2}{*}{ Unknown/unaffected } & 0.001 & 0.001 & 0.001 \\
\hline & Reces & & \\
\hline Biopsy or EMA+ & 0.001 & 0.001 & 0.5 \\
\hline Unknown/unaffected & 0.001 & 0.001 & 0.001 \\
\hline
\end{tabular}

family, a CD case, his sibling and 3 extended relatives had IDDM; in a second family, the CD case had IDDM; in a third family, the mother, 2 siblings, a daughter, and a cousin of a CD case had IDDM; and in a fourth family, the sister of a CD case had IDDM.

The highest 2-point HLOD scores obtained with either model are shown in Table 3. The multipoint HLODs were obtained using the same model as the 2-point HLOD shown. The largest two-point and multi-point LOD scores were obtained in the HLA region. Under the dominant model, the two-point HLOD was $3.1(\alpha=1.0)$ at D6S426 (position 60.4 cM), the multi-point HLOD was $5.02(\alpha=0.66)$ (position $54.6 \mathrm{cM})$, and the NPL was 4.38 ( $\mathrm{p}<$.0001)(position 50.2cM). The estimate for the proportion of families linked was 0.66 for the multipoint HLOD, suggesting that approximately half of the families are linked to an HLA susceptibility locus for CD. Of the 13 candidate gene regions investigated, none of the regions had even nominal evidence for linkage (HLOD > 1.3) or an NPL score with $\mathrm{p}<0.05$.

\section{Discussion}

In this study, we examined linkage to a set of candidate genes for $\mathrm{CD}$. This subset of genes was selected based on genes that could be related to CD through function or an associated disease. For statistical and linkage analysis of complex diseases, we used general recessive and dominant models. Several biostatisticians have suggested that general models provide power to distinguish linkage signals independent of the true underlying disease mode of inheritance, provided both dominant and recessive models are used [38-40]. As expected, the highest two-point and multipoint LOD scores were obtained in the HLA region, with a two-point HLOD of 3.1 and a multipoint HLOD of 5.o. This result replicates the known association and linkage of HLA to CD $[22,25,29]$ and demon- strates the power of the family resource to detect linkage in the set of candidate gene markers.

We were interested in identifying non-HLA loci for celiac disease. We were unable to detect even nominal evidence for linkage at any of the loci investigated. For those regions where we examined only 1 marker, it may be that one marker was insufficient in order to detect linkage even if it existed. A number of candidate genes investigated in this study were examined previously in European populations. Our results are in agreement with previous linkage and/or association studies of CD and Tcell receptor genes (TCR $\alpha, \operatorname{TCR} \gamma, \mathrm{TCR} \beta$, and TCR $\delta$ ), where they saw no evidence for linkage or association, although sample sizes were small $[28,41] . C D 28$ and $C T L A-4$, two genes encoding receptors that regulate Tlymphocyte activation, are located at 2q33. Holopainen et al [24] reported linkage and association to this region in a study of 100 Finnish families with $C D$, which may suggest a possible founder effect in these families. In a case-control study, the CTLA-4 polymorphism, $49 \mathrm{~A}>\mathrm{G}$, was significantly associated with $\mathrm{CD}[\mathrm{p}=0.002$ with an odds ratio of 2.36 (95\% confidence interval 1.37-4.06)] [21]. We did not find evidence for linkage with the CTLA4 polymorphism.

Genomic searches for CD have been conducted in several European populations. In 1996, Zhong et al. [29] studied 40 affected sib pairs from 11 families, and reported significant linkage at 6p23 and weak evidence at 11p11, 7q31.3, 22cen, 15q26, 5q33.3, 19p13.1 and 19q13.2. Houlston et al [42], studying 28 families, found significant evidence for linkage to HLA, but no evidence for linkage to the regions suggested by Zhong, except at $15 \mathrm{q} 26$, where $I D D M 3$ is localized. Greco et al. conducted a genomewide search with 39 sib pairs, and an additional 71 pairs in regions of interest [22]. They found significant evi- 
dence for linkage at HLA and nominal evidence for linkage on 5qter and 11 qter. Using an independent set of 89 sibpairs, they reported additional linkage evidence at $5 \mathrm{q}$ [23]. King et al. [26] performed a genome-wide search with $16 \mathrm{CD}$ families and reported nominal evidence for linkage at 10q23.1 and 16q23.3. In a follow-up study with 50 families, King et al. [27] reported heterogeneity LOD scores $>2.0$ at 5 regions, including 11 p11 previously reported by Zhong et al. [29]. From these studies, the only region with at least nominal evidence for linkage, which overlapped with the candidate regions studied here, was at IDDM3 at $15 \mathrm{q} 26$. One study reported possible evidence for linkage [29], one reported weak evidence [42], and two reported no linkage $[20,22]$. We were unable to detect linkage.

\section{Conclusions}

Our significant evidence of linkage to HLA replicates the known linkage and association of HLA with CD. In our families, likely candidate genes/loci did not explain the susceptibility to CD. It may be that these genes/loci are not involved in $\mathrm{CD}$, that we had insufficient genotyping within regions, or that one, or a number of these genes, has a small effect so that we were unable to detect linkage with our set of families. We were unable to detect linkage at IDDM3 and at CTLA4, for which positive linkages were previously reported. This is similar to the experience in most other reported studies of celiac disease. Non-replication of linkage results in complex diseases is common, and may be due to the low power of studies to detect genes of relatively small effect and/or to a high degree of genetic heterogeneity among families. Larger data sets with more power likely are needed in order to find strong evidence for linkage.

\section{Abbreviations}

CD, celiac disease; HLOD, Heterogeneity LOD: NPL, non-parametric linkage; TCR, T cell receptor

\section{Competing interests}

None declared.

\section{Acknowledgements}

We would like to thank the families for participating in our study. We would like to thank Thao Tran, Kim Nguyen, Michael Hoffman, and Ted Taylor for technical assistance in the laboratory and Jeff Black for family ascertainment. This work was funded by grant ROI -DK50678 from the National Institutes of Health. We gratefully acknowledge the support of the NHLBI Mammalian Genotyping Service for providing some of the genotyping.

\section{References}

I. Not T, Horvath K, Hill I, Partanen J, Hammed A, Magazzu G, Fasano A: Celiac disease risk in the USA: high prevalence of antiendomysium antibodies in healthy blood donors. Scand J of Gastroenterol 1998, 33:494-498

2. Greco L: Epidemiology of coeliac disease. In Coeliac Disease, Proceedings of the International Symposium on Coeliac Disease (M. Maki, P.
Collin, and J.K. Visakorpi, Editors). Tampere, Finland, Institute of Medical Technology, University of Tampere 19979-14

3. Ferreira M, Davies SL, Butler M, Scott D, clark M, Kumar P: Endomysial antibody: is it the best screening test for coeliac disease? Gut 1992, 33( ( 2): 1633-1637

4. Grodzinsky E, Hed J, Skogh T: IgA antiendomysium antibodies have a high predictive value for celiac disease in asymptomatic patients. Allergy 1994, 49:593-597

5. Russo PA, Chartrand LJ, Seidman E: Comparative analysis of serologic screening tests for the initial diagnosis of celiac disease. Pediatrics 1999, 104( I Pt I):75-78

6. Sategna-Guidetti C, Pulitano R, Grosso S, Ferfoglia G: Serum IgA antiendomysium antibody titers as a marker of intestinal involvement and diet compliance in adult celiac sprue. J Clin Gastroenterol 1993, 17:123-127

7. Unsworth F: Serologic diagnosis of gluten sensitive enteropathy. J Clin Path 1996, 49:704-7II

8. Valdimarsson T, Franzen L, Grodzinsky E, Skogh T, Strom M: Is small bowel biopsy necessary in adults with suspected celiac disease and IgA anti-endomysial antibodies? $100 \%$ positive predictive value for celiac disease in adults. Digestive Disease and Science 1996, 41:83-87

9. Volta U, Molinaro M, Fusconi M, Cassani F, Bianchi FB: IgA antiendomysial antibody test: $A$ step forward in celiac disease screening. Digestive Diseases and Science 1991, 36:752-756

10. Volta U, Molinaro N, De Franchis R, Forzenigo L, Landoni M, Fratangelo $\mathrm{D}$, Bianchi FB: Correlation between IgA antiendomysial antibodies and subtotal villous atrophy in dermatitis herpetiformis. J Clin Gastroenterol 1992, I4(4):298-30 I

II. Dieterich W, Laag E, Schopper H, Volta U, Ferguson A, Gillett H, Riecken E, Schuppan D: Autoantibodies to tissue transglutaminase as predictors of celiac disease. Gastroenterol 1998, II 5: |3|7-|32|

12. Sulkanen S, Halttunen T, Laurila K, Kolho K, Korponay-Szabo I, Sarnesto A, Savilahti E, Collin P, Maki M: Tissue transglutaminase autoantibody enzyme-linked immunosorbent assay in detecting celiac disease. Gastroenterol I998, I I 5(6): I 322-1328

13. Kaukinen K, Maki M, Partanen J, Sievanen H, Collin P: Celiac disease without villous atrophy: revision of criteria called for. Dig Dis Sci 200I, 46(4):879-887

14. Sollid LM: HLA susceptibility genes in celiac disease: genetic mapping and role in pathogenesis. Gastroenterol 1993, 105:910922

15. Bevan S, Popat S, Braegger CP, Busch A, O'Donoghue D, Falth-Magnusson K, Ferguson A, Godkin A, Hogberg L, Holmes G, et al: Contribution of the MHC region to the familial risk of coeliac disease. J Med Genet 1999, 36:687-690

16. Lewis C, Book L, Black J, Sawitzke A, Cannon-Albright L, Zone J, Neuhausen S: Celiac disease and human leukocyte antigen genotype: accuracy of diagnosis in self-diagnosed individuals, dosage effect, and sibling risk [In Process Citation]. J Pediatr Gastroenterol Nutr 2000, 3 I (I):22-27

17. Petronzelli F, Bonamico M, Ferrante P, Grillo R, Mora B, Mariani P, Apollonio I, Gemme G, Mazzilli MC: Genetic contribution of the HLA region to the familial clustering of coeliac disease. Ann Hum Genet 1997, 61:307-317

18. Risch N: Assessing the role of HLA-linked and unlinked determinants of disease. Am J Hum Genet 1987, 40:I-I4

19. Strober W: Gluten-Sensitive Enteropathy. In Genetic Basis of Common Diseases (R. King, Rotter, Jl, Motulsky, AG, Editor). New York, New York Oxford Univ Press 1992279-304

20. Brett PM, Yiannakou JY, Morris MA, Rosen Bronson S, Mathew C, Curtis D, Ciclitira PJ: A pedigree-based linkage study of coeliac disease: failure to replicate previous positive findings. Ann Hum Genet 1998, 62:25-32

21. Djilali-Saiah I, Schmitz J, Harfouch-Hammoud E, Mougenot JF, Bach JF, Caillat-Zucman S: CTLA-4 gene polymorphism is associated with predisposition to coeliac disease. Gut 1998, 43(2): 187- I89

22. Greco L, Corazza G, Babron MC, Clot F, Fulchignoni-Lataud MC, Percopo S, Zavattari P, Bouguerra F, Dib C, Tosi R, et al: Genome search in celiac disease. Am J Hum Genet 1998, 62(3):669-675

23. Greco L, Babron MC, Corazza GR, Percopo S, Sica R, Clot F, Fulchignoni-Lataud MC, Zavattari P, Momigliano-Richiardi P, Casari G, et al: Existence of a genetic risk factor on chromosome 5q in Italian coeliac disease families. Ann Hum Genet 200I, 65:35-4I 
24. Holopainen P, Arvas M, Sistonen P, Mustalahti K, Collin P, Maki M, Partanen J: CD28/CTLA4 gene region on chromosome $2 q 33$ confers genetic susceptibility to celiac disease. A linkage and family-based association study. Tissue Antigens 1999, 53(5):470475

25. Houlston RS, Ford D: Genetics of coeliac disease. Q J Med 1996, 89:737-743

26. King AL, Yiannakou JY, Brett PM, Curtis D, Morris MA, Dearlove AM, Rhodes M, Rosen-Bronson S, Mathew C, Ellis HJ, et al: A genomewide family-based linkage study of coeliac disease. Ann Hum Genet 2000, 64:479-490

27. King AL, Fraser JS, Moodie SJ, Curtis D, Dearlove AM, Ellis HJ, RosenBronson S, Ciclitira PJ: Coeliac disease: follow-up linkage study provides further support for existence of a susceptibility locus on chromosome I I I I. Ann Hum Genet 200I, 65:377-386

28. Roschmann E, Wienker TF, Gerok W, Volk BA: T-cell receptor variable genes and genetic susceptibility to celiac disease: an association and linkage study. Gastroenterology 1993, 105(6): 1790-1796

29. Zhong F, McCombs CC, Olson JM, Elston RC, Stevens FM, McCarthy CF, Michalski JP: An autosomal screen for genes that predispose to celiac disease in the western counties of Ireland. Nat Genet 1996, 14(3):329-333

30. Lerner A, Kumar V, lancu T: Immnnological diagnosis of childhood coeliac disease: comparison between antigliadin, antireticulin and antiendimysial antibodies. Clin Exp Immunol 1994, 95:78-82

31. Feolo M, Fuller TC, Taylor M, Zone J], Neuhausen SL: A strategy for high throughput HLA-DQ typing. J Immunol Methods 200I, 258:65-71

32. Cottingham RW Jr, Idury RM, Schaffer AA: Faster sequential genetic linkage computations. Am J Hum Genet I 993, 53( I):252-263

33. Lathrop GM, Lalouel JM, Julier C, Ott J: Strategies for multilocus linkage analysis in humans. Proc Natl Acad Sci USA 1984, 8 I (I I):3443-3446

34. Lathrop GM, Lalouel JM, Julier C, Ott J: Multilocus linkage analysis in humans: detection of linkage and estimation of recombination. Am J Hum Genet 1985, 37(3):482-498

35. Kruglyak L, Daly MJ, Reeve-Daly MP, Lander ES: Parametric and nonparametric linkage analysis: a unified multipoint approach. Am J Hum Genet 1996, 58(6): 1347-1363

36. Ott $\mathrm{J}$ : Linkage probability and its approximate confidence interval under possible heterogeneity. Genet Epidemiol Suppl I986, I:25I-257

37. Ott J: Analysis of Human Genetic Linkage. 3rd ed. Baltimore, Johns Hopkins University Press 1999

38. Clerget-Darpoux F, Bonaiti-Pellie C, Hochez J: Effects of misspecifying genetic parameters in lod score analysis. Biometrics 1986, 42(2):393-399

39. Greenberg DA, Hodge SE, Rotter Jl: Evidence for recessive and against dominant inheritance at the HLA- "linked" locus in coeliac disease. Am J Hum Genet 1982, 34(2):263-277

40. Risch N, Claus E, Guiffra L: Linkage and mode of inheritance in complex traits. In Multipoint mapping and linkage based upon affected pedigree members. Genetic Analysis Workshop 6. Progress in Clinical and Biological Research. (R.C. Elston, M.A. Spence, S.E. Hodge, and J.W. MacCluer, Editors). New York, Alan R. Liss 1989183-189

41. Yiannakou JY, Brett PM, Morris MA, Curtis D, Mathew C, Vaughan R, Rosen-Bronson S, Ciclitira PJ: Family linkage study of the T-cell receptor genes in coeliac disease. Ital J Gastroenterol Hepatol 1999, 3 I (3): | $198-201$

42. Houlston R, Tomlinson I, Ford D, Seal S, Marossy A, Ferguson A, Holmes G, Hosie K, Howdle P, Jewell D, et al: Linkage analysis of candidate regions for coeliac disease genes. Hum Molec Genet 1997, 6:1335-1339

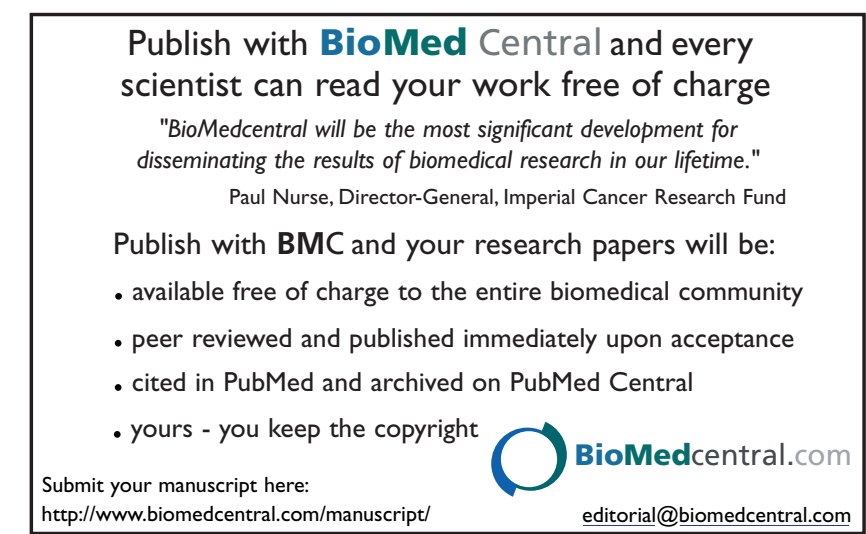

